\title{
Earnings Management before Bankruptcy: A Review of the Literature
}

\author{
Andreas Dutzi and Bastian Rausch \\ University of Siegen, Siegen, Germany \\ Correspondence should be addressed to: Bastian Rausch; bastian.rausch@uni-siegen.de \\ Received date: 18 February 2015; Accepted date: 21 June 2015; Published date: 9 March 2016 \\ Academic Editor: Norshimah Abdul Rahman \\ Copyright @ 2016. Andreas Dutzi and Bastian Rausch .Distributed under Creative Commons CC-BY 4.0

\begin{abstract}
In this article, we will review the evidence on earnings management in distressed firms, in particular, during the periods before filing for bankruptcy. Knowing about the distortion of the accounting numbers through the failing firm is important for all stakeholders who make their decisions based on the firm's annual reports. Over the last years, studies about the accounting behavior of failing firms have become able to present their findings in more detail which enables for better and more intelligible interpretations. In addition, on the basis of a higher level of available information for non-listed firms and the enhancements in the methods for detecting the earnings management, there are more and more options for investigations into the accounting behavior of bankrupt firms. However, the review will show that the results found in the literature about the accounting behavior in distressed firms in the periods before failing are ambiguous. So, as a result of the review, we will show to which extent the existing literature offers consistent findings, we will emphasize the obscure results and point out possible factors which could lead to the different results. In addition, we will identify gaps in research and will propose opportunities for further research on the earnings management in failing firms.
\end{abstract}

Keywords: earnings management, bankruptcy, multi-period examination, accounting behavior

\section{Introduction}

Managerial crises are not a new phenomenon. However, the crisis on the financial market has repeatedly shown that every firm can get into a financial crisis because of various reasons. During such an economic pressure firms are likely to manage the earnings in such a way as to conceal their poor financial condition.
Stakeholders take their decisions related to the distressed firm usually on the basis of its quarterly or annual reports. If a firm is not able to overcome the crisis, it will have to file for insolvency, which may result into an immense economic damage for almost all stakeholders. Hence, stakeholders are interested in detecting the crisis of the respective firm to avoid further financial damage. Within the scope for identifying a crisis of a firm based on its accounting numbers, stakehold-

Cite this Article as: Andreas Dutzi and Bastian Rausch (2016), " Earnings Management before Bankruptcy: A Review of the Literature ", Journal of Accounting and Auditing: Research \& Practice, Vol. 2016 (2016), Article ID 245891, DOI: 10.5171/2016.245891 
ers have to know how the numbers are being influenced. For example, they have to know in which period the firm uses accrual earnings management and in which period real activity earnings management. In addition, an important knowledge for detecting the earnings management and, therefore, for decrypting the real financial condition of a firm, represents the understanding about the impact by the firm on the specific accruals, respectively the items of the financial statement.

Prior studies have investigated many characteristics of earnings management behavior of healthy firms. Some results indicate higher earnings management in code law countries, motivated by their poor investor protection (Leuz et al. 2003). Non-listed firms are known to manage the earnings at a higher level in comparison to listed firms, by reason that they are less monitored than public firms (Ball and Shivakumar 2005). The earnings management can also differ across the economic sectors of a country (Kinnunen et al. 1995). However, do these results correspond to firms in financial distress even, in times before failure?

Research which shows empirical evidence on the earnings management of financially distressed firms is limited (Saleh and Ahmed 2005). Research about the earnings management behavior of bankrupt firms developed primarily within the last ten years. In some cases, there are different results within the studies, which have to be interpreted with caution. In general, studies can offer empirical evidence for signs that the firms use earnings management in the periods before failure. However, one might assume that firms will manage their earnings upwards before filing for insolvency, but several studies show that there are also incentives or factors which can lead to a downwards earnings management. Above all, there are distinctions between the results during each period before failing. By investigating earnings management during firms' financial drawback, it should be considered that a cri- sis lasts more than one period (Fink 2002). Therefore, the time issue represents a very important factor within this research. Detecting earnings management behavior has to take into account that accrual reversals will take place as an inherent cause of accounting standards which can lead to distortionary effects.

The primary aims of this review are to analyze and question the findings of earnings management studies of ex post bankrupt firms as well as to identify gaps which suggest further research activities. These aims lead to the following main research questions of this review:

Are the results about earnings management behavior before bankruptcy really conclusive?

In which research scopes can distinct results be emerged and impact factors be identified which could lead to these differences?

Many studies in this research field already emphasize that there are mixed results in the literature about the accounting behavior during distress periods. This review contributes to the international research in this field as it brings deeper insights about ways to improve research designs. Knowing about earnings management behavior in periods before bankruptcy is important for all stakeholders such as analysts or standard setters.

For example, Kallunki and Martikainen (1999) investigated Finnish bankrupt firms and estimated an upwards earnings management in the three years prior to failure. They also discuss the usefulness of knowing earnings management behavior for failure prediction models. They concluded that income-increasing earnings management is an important variable for predicting financial failure. However, other studies estimate downwards earnings management prior to the failure event. Due to this, there is demand for a closer look on the drivers for these different results. 


\section{Definition and Motivations for Earnings Management}

Earnings management can be interpreted in a beneficial, neutral or a pernicious prospect (Ronen and Yaari 2008). Beneficial earnings management improves the financial reporting by indicating private information on future economic performance and cash flows through management (this view is represented by e.g. Demski et al. 1984, Beneish 2001, Sankar and Subramanyam 2001). In a neutral interpretation of earnings management, the direction of influencing the earnings can be economically efficient as well as an opportunistic behavior for maximizing one's own utility (represented by e.g. Fields et al. 2001, Scott 2003). The damaging interpretation describes earnings management as an instrument for concealing the real financial situation and for misrepresenting financial reports (e.g. Schipper 1989, Healy and Wahlen 1999, Miller and Bahnson 2002). Some authors subsume fraud actions also as a part of earnings management (e.g. Giroux 2006); yet, this is not the prevalent view of the main literature. In a situation of a managerial crisis, there is a probability that the management tries to conceal the poor condition of the firm. So, a disadvantageous interpretation might be suitable for this special situation of bankrupt firms. Following Healy and Wahlen $(1999,368)$, "earnings management occurs when managers use judgment in financial reporting and in structuring transactions to alter financial reports to either mislead some stakeholders about the underlying economic performance of the company or to influence contractual outcomes that depend on reported accounting numbers".

Since at least the 1960s, accounting research has investigated the determinants and implications of accounting choice (Fields et al. 2001). Researchers base their arguments on the fundamentals of Modigliani and Miller (e.g. Holthausen and Leftwich 1983, Watts and Zimmermann 1986 and Fields et al. 2001) who postulate that if there exists a complete and perfect market, there would not be a need for accounting (Modigliani and Miller 1958). However, there are many defects in the market such as misleading numbers or a lack of objectivity (Leftwich 1980). Watts and Zimmermann (1986) emphasize three main alleged market failures: The public good problem describes the inability of a firm to exclude the non-purchasers of a good from using the accounting information which can lead to an underproduction of information. The signaling problem is based on the inherent information asymmetry within the accounting process as well as the speculation problem which can influence the information production by speculations from, in particular, firm outsiders.

Different situations can lead to varied incentives for earnings management. Research literature classifies five comprehensive categories of earnings management incentives (Verbruggen et al. 2008): (I) capital market incentives, (II) signaling/concealing private information, (III) political costs, (IV) increasing CEO's reputation and (V) internal motives. Incontestable, most of the earnings management studies originate from the USA. The US market is known for its distinct capital market ownership. Consequently, most of the studies focus on listed firms. In the sector of capital market incentives, prior studies investigated, for example, that meeting or beating analysts forecast is important for stock returns (Bartov et al. 2002, Matsunaga and Park 2001). Many of the empirical studies discussed in this review will show that in the incentive section of signaling or concealing private information troubled firms manage the earnings to conceal their financial struggle. In addition, there are studies which examine the failed perception through the investors of a strategy with a view to an economic optimizing, like tax planning, by the management (Shane and Stock 2006). Furthermore, some studies recognize how managers can improve the financial information by managing earnings (e.g. Louis and Robinson 2005, Tucker and Zarowing 2006). 
In the political costs section, studies find incentives for a decreasing earnings management to diminish costs for labor renegotiations (D`Souza et al. 2001). Additionally, a decreasing earnings management is taken to reduce taxes in countries in which there is a connection between the financial statement and the tax measurement (Monem 2003). Besides the decreasing earnings management to receive advancements from the government (e.g. Jones (1991), there also exist incentives for increasing earning behavior. This is sometimes needed to fulfill some guidelines given by the government, for example, to offer shares (Haw et al. 2005). CEOs have the natural incentive to present themselves in a good light. If a CEO retires, the CEO will have the ambition to manage earnings upwards before leaving the firm (Reitenga and Tearny 2003). In cases where a new CEO joins the firm, the incentive to blame the old management could arise. Yet, in the first year of management turnover, the CEO manages the earnings downwards. Afterwards, in the year in which the CEOs are responsible for the accounting numbers, they have incentives to manage the earnings upwards for a better light on themselves (Godfrey et al. 2003). Finally, there can be internal incentives for managing earnings upwards motivated, for example, through bonus plans (e.g. Healy 1985, McNichols and Wilson 1988) or for keeping their jobs (e.g. Fudenberg and Tirole 1995). In times of experiencing a crisis, firms have incontestable incentives to manage the earnings upwards to avoid debt covenant violations or to postpone insolvency facts. However, there are also reasons for downwards earnings management like worrying about exposures to litigations.

\section{Concept and Methodology}

\section{Theoretical background of the earnings management before bankruptcy}

In most analyzed studies, but also in many other fields of earnings management research, the theoretical framework and in par- ticular the impact factors of the accounting behavior are not well articulated or developed (as it is also the view of Fields et al. 2001). To derive hypotheses about the accounting behavior during periods before failing, a compact research design is needed. So, first of all we should have a deeper look at the rationale for an earnings management during periods before failure.

Before the accomplishment of the empirical measurement regarding the question whether firms are using earnings management in the periods before bankruptcy, various possible impact factors of the earnings management have to be analyzed. The above discussion of the motivations for earnings management highlights that there are multiple method choices (Fields et al. 2001). First, reflections should take place whether possible impact factors, known by the earnings management research in general, could change during periods of distress. Additionally, the low performance during an economic crisis has to be considered while deriving at the hypotheses about the accounting behavior. For example, if the firm generates losses in the periods focused on, the incentives for downwards earnings management based on saving taxes or achieving dividend reductions will be excluded. It is necessary to consider that the poor financial condition of the firm limits the scope of action regarding the possible earnings management. Moreover, under each research design the level of analysis should not end at the firm level, although we are able to identify relevant context factors, like industry or listing effects. Instead, investigations about earnings management of bankrupt firms have to focus on various impact factors of the decision behavior and characteristics of the top management team.

In addition, findings from related research like studies about the earnings management before debt covenant violations should be included into the research concept. Finally, during an examination of the periods before an event of bankruptcy, one has to take the effects of a multi-period examination into 
account. In the year before bankruptcy, most motives lead to an incentive for upwards earnings management to avoid bankruptcy. However, the accounting behavior in the periods before failing could be affected by more than one conflict. By focusing only on one impact factor, the risk of inappropriate inferences might arise (Dye and Verrecchia 1995). A main distortive effect is represented through reversals of accruals. Every accrual earnings management will reverse in subsequent periods. Over a multi-period observation, there are reversals of accruals in the balance sheet possible which may lead to a finding of downwards earnings management despite the possible earnings management incentive of an upwards earnings management.

\section{Methodology}

Our literature review focuses on papers published between the years 1999 to March, 2014. Particularly, we will be looking at international accounting journals like, among others, the Journal of Accounting and Economics, the Journal of Accounting, the Accounting and Business Research and the Journal of Accounting Research. Conference proceedings and working papers are also included in the review. Used databases were, among others, Wiley Online Library, ScienceDirect, EBSCOHost and the Social Science Research Network. Keywords are phrases like distress, bankruptcy, earnings management, failure and accounting choice.

In order to gain a deeper understanding of the earnings management behavior, we will focus in our analysis only on distressed firms which went into bankruptcy. However, results of studies about the accounting behavior of distressed firms which survived thereafter should not be completely omitted in the analysis. Ronen and Yaari (2008) describe possible events in the life cycle of a debt covenant violation. They divide the life cycle into five periods, from inception, technical default across debt service violation to bankruptcy, before the last period is represented by liquidation. It is not unlikely that many firms exhibit debt covenant violations before the bankruptcy event. The debt covenant hypothesis is thoroughly researched (for a summary Ronen and Yaari 2008). This hypothesis postulates that accounting choice is executed in a manner to reduce the possibility of technical default. With regard to the investigation of bankrupt firms in a multi-period context under consideration of possible life cycles, the debt covenant hypothesis can be an underlying rationale in the periods before bankruptcy. Therefore, we should expect that this theoretical basis is included in the research designs of the analyzed studies about the earnings management of bankrupt firms. Hence, we will take a look into studies during the years 1990 to 2014, which investigated distressed survived firms by providing relevant information for the analysis of the bankrupt studies we focus on.

Research on bankruptcy shows that the accounting numbers of bankrupt firms have been changed in more than only one period before the bankruptcy event (Beaver 1966). In particular, a possible income increasing earnings management based on the debt covenant hypothesis in earlier periods can lead to distorted results against possible earnings management incentives. This is caused by the smaller opportunities of a possible earnings management determined by the low performance or reversals of accruals. Thus, we will limit the review to only those studies which focus on a multi-period examination of bankrupt firms.

Many studies already postulate that there are mixed results in the research about the accounting behavior of distressed firms (e.g. Charitou et al. 2007b, Lara et al. 2009, Etemadi et al. 2012 and Franceschetti and Koschtial 2013). Therefore, we will structure our analysis in a way as to clarify this drawback. In this context, we will ask the questions, which topics elicit clear results, which topics generate mixed results and whether we can identify those impact factors which 
may explain these ambiguous results. We will offer an analysis of the studies in three steps. In the first step, we will look at the research design, expecting to see differences in the underling research concepts as a basis for deriving at hypotheses since the results are mixed results. In the second step, the studies will be analyzed regarding their findings about the earnings management in each period before the bankruptcy event. In this phase, we will review the special research topics for identifying commonalities like the effect of audit opinion on the earnings management of bankrupt firms. Finally, we will analyze the studies according to special impact factors which could lead to the existing mixed results.

\section{Earnings management methods and de- tection models}

\section{Earnings management methods}

Studies commonly differentiate between four different categories of earnings management through (I) specific accruals, (II) cost allocation or income shifting, (III) disclosure management and (IV) real activities (e.g. Mohapatra 2011, Verbruggen et al. 2008). Adjustments in specific accrual accounts, like allowances for doubtful accounts (e.g. Capalbo 2003), offer a wide area of discretion for managers. In addition, managers can alter the accounting numbers by adding various cost elements to different cost centers in a way that cost allocation results may lead to distortive decisions. Otherwise, they can shift costs or revenues from one subsidiary to another in view of a tax optimizing strategy (e.g. Krull 2004). Voluntary disclosures signal intended information to the stakeholder and, thereby, reveal the financial numbers in a different light. Finally, earnings management could be also a result of real activities (Roychowdhury 2006). Unlike accrual-based earnings management, managers are always able to change the normal course of operations to mislead at least some stakeholders. Real earnings management is any kind of new contractual arrangement or transaction that leads to a desired level of earnings by, for example, price discounts for increasing sales or R\&D budget cuts.

\section{Developing of earnings management de- tection models}

Empirical evidence is predominantly given by quantitative detection models. Qualitative models are often very extensive as well as unable to measure the magnitude of earnings management. However, they have the ability to give hints to the direction of earnings management by discovering changes in accounting policies (Naidu and Patel 2013). In addition, the variations of the accounting policies may give notes of which practical measures are used to affect the earnings.

The majority part of quantitative empirical studies uses aggregate unexpected accruals for detecting earnings management. This also applies for most of the studies examining the earnings management of failing firms. A first model was developed by Healy (1985) which is primarily based on total accruals, measured as the change in non-cash working capital before income taxes payable less total depreciation expense. Normal accruals are defined as the deflated long-run accruals. Another model was devolved by DeAngelo (1986, 1988). She measures the normal accruals as the previous period's accruals divided by lagged assets. This leads to the assumption of a random walk process where the expected accruals of the actual year are equal to those of the last year and thus all changes in accruals shall be discretionary. Dechow and Sloan (1991) based their model on the industry as a type of classification criterion. The normal accruals are calculated as the difference between the total accruals of the respective firm and the median of the specific industry. The assumption of all of these models is that discretionary accruals are an absolute term over the periods. The advantage is that these models do not need long time-series investigations, but they can obviously lead to enormous measurement mistakes based on this static view. 
Many empirical studies use an adoption of the so called Jones model (Jones 1991). This model estimates the expected normal accruals with the assumption of no earnings management and compares them with actual accruals, whereupon the difference between these two extents represents the proxy for earnings management. The Jones model considers changes in revenues and property plant and equipment as the primarily influenced dimensions. So far, the Jones model has been adjusted many times. Dechow et al. (1995) modified the Jones model by integrating accounts receivables into the model. The first stage of this estimation of normal accruals is the same as in the Jones model, but in the second stage the subtraction of the receivables takes place. The authors subtract the receivables from the revenues, because they emphasize the possibility of influencing this balance sheet item. Likewise, a deficit of this model is finally that it is based on the assumption that all changes in receivables are affected by earnings management. A further modification by Dechow et al. (2003) added a separation of the normal accruals and the discretionary accruals in credit sales, as well as they include a control for the decelerated accruals and the growth. Moreover, there are also developments which adjust the Jones model to an influence by performance. Kang and Sivaramakrishnan (1995) consider the cash flow as a regressor; in contrast, Kasznik (1999) focused on cash flow effects over the period, constituted by the negative correlation of accruals and cash flow (Dechow 1994). The performance-matching model by Kothari et al. (2005) is motivated by the consideration of the non-linear relationship between normal accruals and performance by implementing return on assets into the model. Many developments and adjustments of these models have been followed; a well-known study which examines real activities manipulation is by Roychowdhury (2006). He grounds a linear function of sales and changes in sales as the normal cash flows in the current period. Equally, expenses are expressed as a linear function of contemporaneous sales in the model. Abnormally, high production costs in relation to a fixed sales level are interpreted as sales manipulation based on abnormal price reductions or grounded by a COGS expense manipulation by an overproduction (Roychowdhury 2003, Gunny 2006).

Besides these major studies of the accrualbased measurement of earnings management, there are various alternative methodologies for detecting it. Some studies concentrate on the investigation of single accounts. These approaches often focus on single income statement items, for example write-offs (e.g. Dowdell and Press 2004). The main advantage of a single account analysis in comparison to the total accruals is the possibility of a more detailed inspection and following superior statements about unmanaged accounting standards. However, a focus on single accounts cannot explain whether other items are managed at the same time. Another well-known measurement approach is the distributional approach (e.g. Burgstahler and Dichev 1997). This model assumes a Gaussian distribution of unmanaged earnings and interprets earnings management as the difference to the observed earnings.

One helpful approach regarding a multiperiod examination is taking into account that any interference in accruals at one point of time will lead to a reversal in one of the following periods (Dechow et al. 2012). Such new approach could consider the dynamic process in an intensified manner and could potentially increase the statistical power of earnings management detection models (Gerakos 2012). The present review on the empirical studies about the accounting behavior of failing firms will show that the research in this area has grown in connection with the development of new measurement possibilities on the detection of earnings management. 


\section{Review of the empirical evidence for earn- ings management of failing firms}

\section{The crisis to the point of no return}

Prior studies on earnings management during managerial crises use proxy variables like persistent losses, dividend reductions (DeAngelo et al. 1994) or debt renegotiations (Saleh and Ahmed 2005). Some other studies focus on the earnings management during the influence of external financial crises like the financial market crisis in the past years as a circumstance of a distress (Latridis and Dimitras 2013). The characteristics of the term bankruptcy can differ from country to country. Often the expression bankruptcy is pronounced as the end of the economic architecture of the observed firm. In any case, bigger firms will partially persist after filing for bankruptcy, even if not in the same structure or under the same name. In many countries, there are also legal structures which support a reorganization of the firm. For example, the British insolvency code provides three options during financial distress. An administration order leads to a control of the probably failing firm by an administrator. The administrative receivership is interference by a receiver to primarily keep bank borrowings. The third option represents the liquidation or winding up of the firm. In code law countries like most in Europe there are also likewise regulations. For example, the German insolvency law codifies the insolvency of the matters of fact inability to pay the claims or balance sheet over-indebtedness.

However, there are also explicit structures and rules based on the law which enable for a reorganization of the firm by an insolvency plan procedure. In some cases, studies about the earnings management in distressed firms cannot explicitly separate into the distressed or bankrupt area. For example, in an Iranian study by Etemadi et al. (2012) about earnings management in bankrupt firms in Iran, the authors define, according to article 141 of the Iranian commercial code, a firm as bankrupt if the firm retains losses further than half of its payments in capital. Although every firm filing for insolvency finds itself in a financial distress condition in one or multiple periods before filing, we separate the studies which focus primarily on distressed firms and studies which focus on bankrupt firms. The studies about distressed firms in common concentrate on distress proxies, whereas empirical studies about bankrupt firms can analyze the accounting behavior in a specific way, in particular, they can perform a better multi-period examination.

\section{Earnings management during managerial crises}

Empirical studies which use proxies for the financial distress of firms have been primarily gathered over the last twenty-five years. Many studies deal with the debt-covenant hypothesis (e.g. Dichev and Skinner 2002), changes in dividend policies as a proxy variable for distress (e.g. DeAngelo and DeAngelo 1990) or circumstances prior to technical defaults (e.g. HassabElnaby et al. 2005), and examine the practiced earnings management under different aspects and research questions. An early study by Healy and Papelu (1990) examines the earnings management around a dividend cut. For detecting earnings management, they analyze changes in the accounting choices which are assumed to be earnings management, for example, depreciation methods or the amortization period for intangibles. However, their findings signal no significant accounting changes around the event. Beneish and Press (1993), who also focus on the measuring of accounting choices, come to an increasing direction of earnings management; likewise Lilien et al. (1998) also find income increasing accounting behavior of unsuccessful firms.

A first well-known accrual based approach is supported by DeAngelo et al. (1994), who examine the accounting choice of troubled firms. They use as a proxy for earnings management, among others, the abnormal accruals as the difference between income and cash flow from operations. Their results 
show only in year t-3 prior to the dividend reduction significant income increasing earnings management. In the years $\mathrm{t}-1$ to $\mathrm{t}-10$ no significant earnings management is found, but their results show large negative accruals in the years 0 to 3 after the event period. De Fond and Jiambalvo (1994) examine firms with debt covenant violations during the years 1985 to 1988. For estimating the normal accruals, time-series and cross-sectional models are used. They locate significant positive abnormal total and working capital accruals one year before the covenant violation. In the year of violation, negative abnormal total accruals and working capital accruals are found. At the end of their study, some hints for possible distortions of their results are given. One of these biases represents a management turnover in the year of violation which is observed in 27 of the 94 examined firms. Prior literature gives insight that managers may have incentives to choose downwards earnings management in order to blame the old management in the first year of management changes and afterwards they manage the earnings upwards to cast a better light on themselves (Pourciau 1993). Thus, the study gives evidence for positive manipulation in the year of debt covenant violation. As a result, we should assume that in times of covenant violations the pressure could be too low to give explicit incentives for a predominate upwards earnings management. Sweeny (1994) underpins the hypothesis of an upwards earnings management by analyzing US firms during the years 1980 to 1989 by examining accounting changes. Saleh and Ahmed (2005) examine the earnings management during debt contract renegotiations in distressed firms in Malaysia. The investigation period takes place from 1998 to 1999 during the Asian financial crisis. They find evidence for downwards earnings management during the year of the renegotiations with lenders. Peltier (1999) examines the accounting behavior of troubled firms with a view to a non-routine management change. The accrual-based examination confirms decreasing earnings management during the year of a change in management.
Burgstahler and Dichev (1997) devote themselves to the question whether firms manage earnings to avoid earnings decreases and losses. They examine the earnings management behavior of firms during the years 1977 to 1994 and use a cross-sectional distribution approach for measuring. The results indicate uncommonly high frequencies in small positive income and they can show that the two components, cash flow from operations and changes in working capital, are used to avoid small losses. The incentive component is directed to avoid negative capital market reaction. Thus, it is not surprising that earnings management is more used to avoid small losses than to avoid earnings decreases caused by a limited potential of the earning management impact.

Leuz et al. (2003) examine the different accounting behaviors across 31 countries. They explain the difference with an attempt of the managers to protect their private benefits by using earnings management to conceal firm performance from outsiders. Beneish et al. (2012) investigate firms preceding technical default. They provide evidence that the choices of managers in context of their trading and accounting behavior are influenced by the threats of litigations. They come to the conclusion that more than half of the managers disclaim earnings management in these cases.

\section{Earnings management before bank-ruptcy}

\section{Studies about the earnings behavior in bankrupt firms}

Empirical research about the accounting behavior before filing for insolvency is still young and has been primarily developed within the last decade. An early study about the accounting behavior in periods before failing is conducted by Smith et al. (2001). The study examines changes in accounting policies one year prior to insolvency in Australian firms. The results show that firms classified only as distressed indicate a significant tendency for income increasing account- 
ing policy changes. However, failed firms do not use income increasing measures more than healthy firms out of a control group. As the authors suggest, a possible reason for this is that the management might be a sure prospect of imminent settling up, with possible consequences of litigation against directors, auditors, or others. This could be based on various factors such as a lack in the research design, a missing multi-period examination or drawbacks in the measuring model.

Other studies focus only on one or a small number of firms. Jorissen and Otley (2010) examine the exogenous and endogenous character of variables in the context of possible earnings management by using internal firm data. They investigate the bankruptcy of the SAirgroup as the parent firm of Swissair during the year 2001. The authors reject commonly used assumptions, for example, that some internal factors like firm contracts are only exogenous, and include the influence of them in their analysis. As a result, they can document that some exogenous factors play a role for managing earnings and that most of the empirical research distinguish these dependent and independent variables incorrectly. However, these kinds of case studies help us to get a better understanding of the management behavior in particular situations, although their general evidence remains limited.

A study by Li et al. (2011) analyzes the effect of earnings quality in relation to the stress level and bankruptcy level of listed firms in China during the periods 2003 to 2007. Besides the focus on accrual measurement, the authors measure the earnings quality by earnings persistence, earnings predictability and earnings smoothness. The authors define the case of opportunistic earnings management as an absence of efficient communication of private information in a positive manner and instead of that a concealment of this information. Their results show also an opportunistic earnings management of stressed, bankrupt firms. However, they cannot execute the need of a detailed focus on each period because of their measurement comparisons regarding the earnings quality. The same lack regarding the research question of this review shows a study by Charitou et al. (2011). In this study the authors investigate the link between distress risk, growth and earnings quality, which is examined with two proxies as alternative measures of earnings quality, namely earnings timeliness and earnings management towards a positive target. The results show that the relation between earnings quality and financial health is not monotonic.

\section{Empirical research with a multi-period examination focus}

As described above, we focus only on studies which examine bankrupt firms in a multiperiod context. According to the high number of studies based on measuring discretionary accruals and for a better understanding of possible impact factors related to the ambiguous results, we will concentrate our analysis only on accrual based studies. After a selection of the literature based on these characteristics, we will now concentrate our analysis on 8 remaining studies: 
Table 1: Accrual based studies with a multi-period examination focus

\begin{tabular}{|c|c|c|c|c|}
\hline Study & Sample & Model & Research focus & Impact factors \\
\hline $\begin{array}{c}\text { Kallunki and } \\
\text { Martikainen (1999) }\end{array}$ & $\begin{array}{l}\text { 1983-1989 } \\
\text { Finnish fiems }\end{array}$ & $\begin{array}{l}\text { Extent of discretionary } \\
\text { accruals from } \\
\text { income statement }\end{array}$ & $\begin{array}{l}\text { Country-specific investigation, } \\
\text { usefulness for insolvency } \\
\text { prediction models }\end{array}$ & $\begin{array}{l}\text { Listing } \\
\text { law system }\end{array}$ \\
\hline Rosner (2003) & $\begin{array}{l}\text { 1985-1997 } \\
\text { US firms }\end{array}$ & $\begin{array}{l}\text { Earnings manipulation } \\
\text { proxy variables, } \\
\text { Dechow et al. (1995) }\end{array}$ & $\begin{array}{c}\text { Performance classification and EM, } \\
\text { ratio analysis, } \\
\text { comparison with fraud firms, } \\
\text { influence of auditor opinion }\end{array}$ & $\begin{array}{l}\text { Listing, law system, } \\
\text { stress-level, } \\
\text { audit-opinion }\end{array}$ \\
\hline $\begin{array}{l}\text { Charitou et al. } \\
\text { (2007a) }\end{array}$ & $\begin{array}{c}\text { 1986-2001 } \\
\text { US firms }\end{array}$ & $\begin{array}{l}\text { Theo et al. (1998), } \\
\text { Dechow et al. (1995) }\end{array}$ & $\begin{array}{l}\text { Influence of auditor opinion, } \\
\text { chance of survival through EM, } \\
\text { CDA vs. LDA }\end{array}$ & $\begin{array}{l}\text { Listing, law system, } \\
\text { stress-level, } \\
\text { audit-opinion }\end{array}$ \\
\hline $\begin{array}{l}\text { Charitou et al. } \\
\text { (2007b) }\end{array}$ & $\begin{array}{l}\text { 1986-2004 } \\
\text { US firms }\end{array}$ & Kothari et al. (2005) & $\begin{array}{l}\text { Influence of govemance structures } \\
\text { expressed by management turnovers } \\
\text { and institutional ownerghip. } \\
\text { influence of auditor opinion }\end{array}$ & $\begin{array}{l}\text { Listing, law system, } \\
\text { audit-opinion. } \\
\text { management turnover, } \\
\text { governance-structure }\end{array}$ \\
\hline $\begin{array}{c}\text { Leach and } \\
\text { Newsom (2007) }\end{array}$ & $\begin{array}{l}1980-2000 \\
\text { US firms }\end{array}$ & Theo et al. (1998) & $\begin{array}{l}\text { Country-specific investigation, } \\
\text { comparison with fraud firms }\end{array}$ & $\begin{array}{l}\text { Listing } \\
\text { law system }\end{array}$ \\
\hline Lata et al. (2009) & $\begin{array}{l}\text { 1998-2004 } \\
\text { UK and } \\
\text { Ireland }\end{array}$ & $\begin{array}{c}\text { Kasznik (1999), } \\
\text { Roychowdhury (2006) }\end{array}$ & $\begin{array}{c}\text { Performance classification and EM, } \\
\text { measurement of accrual } \\
\text { and real EM }\end{array}$ & $\begin{array}{l}\text { Listing } \\
\text { law system, } \\
\text { stress-lewel }\end{array}$ \\
\hline $\begin{array}{l}\text { Etemadi et al. } \\
\text { (2012) }\end{array}$ & $\begin{array}{l}2006-2009 \\
\text { Iran }\end{array}$ & Kothari et al. (2005) & $\begin{array}{l}\text { Country-specific investigation with } \\
\text { focus on a developing country }\end{array}$ & $\begin{array}{l}\text { Listing } \\
\text { economic envitomment }\end{array}$ \\
\hline $\begin{array}{l}\text { Campa and } \\
\text { Camarho-Mifiano } \\
\text { (2014) }\end{array}$ & $\begin{array}{l}\text { May to } \\
\text { June } 2010 \\
\text { Spain }\end{array}$ & $\begin{array}{c}\text { Kasznil: (1999), } \\
\text { Ropychowdhury (2006) }\end{array}$ & $\begin{array}{c}\text { lnvestigation of SMEs, } \\
\text { country-specific investigation. } \\
\text { Comparison between four industries }\end{array}$ & $\begin{array}{l}\text { Listing } \\
\text { law system, } \\
\text { fndustry }\end{array}$ \\
\hline
\end{tabular}

The time period in the sample column represents the dates on which the firms filed for bankruptcy. We listed the authors who developed the fundamentals of the used methods in each study. Due to the use of accruals measurement models, we do not analyze the studies in detail with regard to a comparison of the used measurement models. We will point out the investigation topics of each study with which the authors reason their estimation. In addition, we will try to identify possible impact factors of the results about the earnings management behavior in the studies, which are known through the general earnings management literature (see for an extensive discussion of the determinants of earnings management Dechow et al. 2010).

\section{Research design}

First of all, we will interpret the research designs with regards to possible elementary differences between the studies. In general, the papers are structured in the same way and start with a brief discussion about incentives for a downwards or upwards earnings management in the periods before failing. In addition, depending on the research topic, there are additional explanations about the incentives for managing earnings in these contexts. The main research hypotheses like contractual theory, debt covenant hypothesis or the conservatism hypothesis are mentioned in some studies, but not discussed deep enough relating to their research topic. As known from studies in other earnings management research fields, the theoretical discussion of the underlying concepts is briefly articulated in the papers. In cases in which the studies offer an empirical result differing from other findings, the authors determine their statements often only by reasoning their own findings, but do not address the issue in the form of comparing and discussing the differences. Sometimes the findings are the same, but the interpretations differ from each other. Starting at this point, 
there is a need for further discussions which is necessary for implementing the results into practice. Furthermore, a complete research design depending on the individual research situation as described in chapter 3.1 is missing in the studies. Regarding this evaluation topic, we conclude that there is still a lack of a sound theoretical framework.

\section{Empirical results}

In this step, we will analyze which findings are predominantly consistent and which findings are ambiguous. First of all, we will present the findings of earnings management behavior in general regarding the various periods before failing without any special context factors. After that, we will classify the two context factors stress level and audit opinion which are measured by at least two papers.

\section{Empirical results in general}

The first multi-period study which is based on discretionary accruals is represented by Kallunki and Martikainen (1999). The authors examine changes of the adjusted income in Finnish firms by measuring earnings management in the six periods prior to failure. They examine a significantly upwards earnings management in the three periods before failure. In the preceding periods earnings management is not significantly different from zero.

Another more extensive accrual based study about the accounting behavior of US failing firms is developed by Rosner (2003). One primary question referred to in that case is whether failing firms' pre-bankruptcy financial statements are more likely to exhibit signs of material income increasing earnings manipulation than those of non-failing firms. For measuring the accounting manipulation, she uses material earnings manipulation proxy variables which are derived from earnings management and fraud literature. The proxy variables focus on the aggregate and specific accruals detection of misspecifica- tions of accounting items. On the aggregate level, she finds significant increases on discretionary accruals. The specific accrual investigation shows also significant greater magnitudes in receivables, inventories, property plant and equipment, sales, net working capital and current accruals. Furthermore, the failed firms reveal significantly more negative changes in cash flows from operations and net cash as a greater disparity between accrual-based net income and operating cash flows. However, Rosner pooled all the five investigation years together and does not separate the results for each of the five examined years prior to failing.

Charitou et al. (2007a) find in their examination of US firms downwards earnings management one year prior to insolvency. In a second study which had been motivated by special aspects like the influence of institutional ownership, Charitou et al. (2007b) confirm their finding of a downwards earnings management prior to bankruptcy filing.

A study by Leach and Newsom (2007) examine the five years prior to the insolvency of US listed firms. Their results show a significant upwards earnings management in period five and four prior to insolvency. During the periods three to one prior to insolvency, the direction changes and they find downwards earnings management, whereupon the year $\mathrm{t}-2$ and $\mathrm{t}-1$ are significant.

Lara et al. (2009) examine the earnings management behavior during the four years prior to the insolvency of listed firms in the UK and Ireland. They find upwards earnings management in the years t- 4 to $t-2$ prior to insolvency. In the year just before failure they provide evidence for downwards accrual earnings management reasoned by unravels.

Etemadi et al. (2012) investigate Iranian bankrupt firms related to their earnings management behavior in the five years prior to insolvency, seen as the first study on earnings management before bankruptcy within a developing country. The authors observe an increasing earnings management only in pe- 
riod five prior to insolvency. During the periods four to the year of failure they find decreasing earnings management. The level of discretionary accruals is at the highest rate one year prior to failure. In the year during bankruptcy, the discretionary accruals are also negative, but with a lower level likewise in period $\mathrm{t}-2$.

A current study by Campa and CamachoMiñano (2014) investigates as one of the first study in this research field, non-listed firms in Spain. They examine the three years prior to the bankruptcy event. Their results show that firms manage the earnings upwards in the whole three years prior to filing.

It becomes clear that there are mixed results with regard to the direction of the measured earnings management in each period. As described above, the review of the research concepts shows no rigor theoretical explanation for the differences. For example, Leach and Newsom justify their findings with the assumption that in year five an upwards earnings management is used to conceal the poor financial condition. From period four to failure, the earnings management capacity should still comply with the GAAP. The interpretation for a significant level of downwards earnings management is that the firms start to write off uncollectible receivables. This behavior could be a result of applying GAAP in a regular way so it may not be caused by earnings management incentives necessarily. The indecisive interpretations of their results also reveal the deficits in the measurement models. An interpretation of the incentive for upwards earnings management already in period five before failure can only be given in dependence to an individual analysis of the firms to proof their financial conditions at this time.

\section{Category - Stress level}

The earnings management under consideration of the individual stress level of the firms is measured by the study from Rosner (2003) and Lara et al. (2009). Rosner classifies the firms in stressed and non-stressed firms by adapting the criteria by McKeown et al. (1991). They classify firms as stressed if a firm fulfills one of the four criteria: (I) negative working capital in the current year, (II) a loss from operations in any of the three years prior to bankruptcy, (III) a retained earnings deficit in year t-3, or (IV) a bottom-line loss in any of the last three pre bankruptcy years. Rosner finds that bankrupt firms which are classified as non-stressed reflect significantly income increasing behavior than do control firms. Stressed bankrupt firms show also significantly increasing accounting behavior but with a lower magnitude. Lara et al. use in their investigation a failure prediction model from Charitou et al. (2004), based on a logit methodology to classify the sample in bankrupt firms with an ex-ante low or high bankruptcy probability. They find more aggressive accruals earnings management in bankrupt firms with a low probability of bankruptcy in accordance with Rosner.

In summary, bankrupt firms which seem to be more healthy in pre-bankrupt periods engage in an upwards earnings management in a much more intense way than ex-post bankrupt firms which seem unhealthy in prebankrupt periods. Lara et al. interpret this result as a successfully hiding poor performance. However, these findings have to be interpreted with caution since firms which are classified as stressed, have a generally high probability of bankruptcy and may have already exhausted their opportunities for earnings management; thus earnings management may reverse or the poor performance does not allow enough scope for further earnings management.

\section{Category - Audit opinion}

Rosner (2003) compares going-concern years with non-going concern years of their bankrupt sample. She finds an income decreasing earnings management of firms with a going-concern opinion, especially in period $\mathrm{t}-1$, and in comparison with non-goingconcern opinion firms in which she finds in- 
come increasing behavior. She causes the decreasing results with overstatement reversals. Charitou et al. (2007a) use a broader definition than going-concern by implementing the qualified audit opinion as a classification scale. They find that bankrupt firms which receive an unqualified audit opinion in year $\mathrm{t}-5$ or $\mathrm{t}-4$ prior to failing are engaged in upwards earnings management in subsequent periods. Firms which receive a qualified audit opinion in $\mathrm{t}-2$ or $\mathrm{t}-1$ show a decreasing earnings behavior in the following period. They explain this behavior by the fact that firms will react more conservative if the financial distress becomes public through the audit opinion. In the second study by Charitou et al. (2007b), they confirm their results with additional caution that the auditors of distress firms are more conservative of their financial choices which lead to non-cash write-offs or dividend reductions. These results are also confirmed by Etemadi et al. (2013) and Arnedo et al. (2008). Arnedo et al. investigate Spanish firms one year prior to insolvency and find a decreasing earnings management of going concern opinion firms; like Rosner they justify this result with reversals of previous overstatements.

Rosner (2003) and Charitou et al. (2007b) find downwards earnings management prior to insolvency depending on the going concern opinion respectively the audit opinion. However, Rosner interprets the results as reversals, arguing against Charitou et al. who hypothesize this as earnings decreasing behavior based on the conservatism hypothesis cause by audit opinions.

In conclusion, the studies show evidence for earnings management before bankruptcy measured by earnings management accruals. However, the results in each period before the failing event are mixed. Indeed, in the two sections of stress level and audit opinion we find concurrent findings between the studies which examined this topic. In the last step regarding the mixed results, we will discuss factors which are known by the general earnings management literature to have an impact on the earnings management behavior.

\section{Impact factors}

Charitou et al. (2007b) consider in their estimation a possible effect through a management turnover. They confirm the hypothesis that a new management blames the old management in the year of changing and, thereafter, push the accounting numbers upwards to show themselves in a better light. The authors show the highest level of management turnover in year $\mathrm{t}-1$. Their result of a decreasing earnings management in this period confirms the hypotheses. DeFond and Jiambalvo (1994) find that 29\% of firms with debt covenant violation have a management turnover. As in the study by DeFond and Jiambalvo, after adjusting the estimation for a management turnover, the empirical results change. Therefore, under consideration of the possible life cycle of a debt covenant, postulated by Ronen and Yaari, studies about earnings management before bankruptcy should consider the effect of a possible management turnover in periods before insolvency.

Charitou et al. (2007b) regards the influence of institutional ownership on the earnings management of bankrupt firms as another possible factor. They find that firms with a lower institutional ownership have a greater tendency to manage the earnings downwards. They argue that a higher institutional ownership executes a higher level of control on the firms so that the earnings management decreases. In this section, there are many possible governance structures which may pose influence on the possible earnings management and which may offer themselves a valuable topic for further research.

Lara et al. (2009) take their focus besides on the measuring of accrual earnings management also on measuring real activities. They show that firms manage the earnings upwards by accrual earnings management in the years $t-4$ to $t-2$. In year $t-1$, they find 
downwards earnings management, caused by reversals of accruals. In addition, in this period they estimate real activity earnings management. They argue that the scope for accrual earnings management is exhausted at that time and, therefore, the firms engage in higher costly real activity earnings management. This points to the situation that there are other kinds of possible earnings management besides accrual earnings management which have to be considered in the investigation.

The study by Campa and Camacho-Miñano measures an upwards earnings management three years before bankruptcy filing. The earnings are managed through accrual and real activities whereby the use of real activity earnings management stop immediately before the filing event; a result much in contrast to Lara et al's. Campa and Camacho-Miñano look at non-listed firms in the code law country Spain. To measure possible influences of these factors is welcome, but they should take more interest in the differences presented in other studies. They show that there is a difference in the earnings behavior between industries. In addition, they assume a different behavior between case and code law countries. However, under consideration of the discussed above, the authors are not able to separate the influence of the code law system. The same case is provided for listed versus non-listed firms. As known from other parts of earnings management literature, earnings management in non-listed firms should be higher. Yet, to include this impact factor there is a need for a more extensive theoretical discussion about possible influences within to this topic.

This evaluation topic shows that there are many impact factors which can affect the earnings management behavior. It turns out that there is further need for contextual earnings management studies.

\section{Conclusion and prospects for future re- search}

Earnings management research about the accounting behavior of distressed firms has been primarily developed during the last twenty-five years. Research focusing on earnings management before bankruptcy is still younger and has been preponderantly gathered over the last ten years. The studies establish the existence of earnings management, but they provide heterogeneous results with regard to the direction of earnings management during the various periods. Therefore, this review shed light on areas with consistent findings, ambiguous results and the factors that could lead to these mixed results. For this purpose, we limited the review on multi-period accrual based studies which investigate bankrupt firms. We evaluated the studies in three steps: the research design, results and impact factors.

Relating to the research design, the review illustrates that there is still a lack of a comprehensive theoretical framework. This drawback leads to various hypotheses and ambiguous results in the studies. A new research design for a multi-period accounting behavior during periods before insolvency needs to be further modified, especially by using analytical models.

Regarding the empirical results, the review shows that there are different incentives for managing earnings. In periods of crises, there are upwards earnings management incentives as well as incentives which may lead to downwards earnings management. Only in the period prior to the bankruptcy event, most of the studies agree on downwards earnings management. However, the reasons for these results, the opinions are not uniform. Some authors denominate the incentives view for motivation, others argue with reversals of accruals. In two identified sections, the stress level and audit opinion, there are consistent results. Bankrupt firms which seem to be non-stressed manage the earnings in an intensified manner in comparison 
to stressed firms. Bankrupt firms which receive a qualified audit opinion manage the earnings downwards compared to firms with a non-qualified audit opinion which engage in upwards earnings management.

The third assessment step shows that there are impact factors, like a management turnover, which can lead to distorted results if this factor is not considered in the investigation. The main earnings management research is found in the US in general and focuses on listed firms (Verbruggen et al. 2008, Campa and Camacho-Miñano 2014); the same is true for the field of financial distressed firms. So, there is still a need for more research in other countries and for investigations concerning non-US firms and equally non-listed firms. In addition, investigations should take a focus on further firm and management characteristics, for example, ownership structure, audit committee composition or family involvement. A more detailed investigation is also needed within the examinations of real earnings management. Current studies by Lara et al. and Campa and Camacho-Miñano pay attention to these requirements but should be further advanced. In conclusion, future research should work more on contextual earnings management studies or may take the focus on further examination topics like psychological traits of managers during the times of crisis (The same result is put forward by Vladu (2013) who gives a short insight about the literature regarding earnings management during the times of financial crisis).

In general, further research is necessary with regards to the accounting behavior of distressed firms, which should be conducted more in detail (Charitou et al. 2007a). To bring more clarification into the reversal question, the current approach by Dechow et al. could be integrated in the measurement process. For solving this question, the splitting process of current and long-term accruals in the investigation could be further developed. In addition, there could be other measurement methods used which can forti- fy the accounting behavior in detail, for example specific accrual detection models. Furthermore, alternative models like the procedure by Jorissen and Otley could be used in connection, both as a complement and a comparison to the typical accrual based models.

Knowing about the accounting behavior of bankrupt firms is important for all stakeholders. As the study by Lara et al. (2009) proposes, firms are successful in hiding the poor condition; therefore, we need more information about the earnings management in the periods before bankruptcy since it enables us to develop insolvency prediction models.

\section{References}

1. Arnedo, L., Lizarraga, F. and Sánchez, S. (2008), 'Going-concern Uncertainties in Prebankrupt Audit Reports: New Evidence Regarding Discretionary Accruals and Wording Ambiguity,' International Journal of Auditing $12,25-44$.

2. Ball, R. and Shivakumar, L. (2005), 'Earnings quality in UK private firms: comparative loss recognition timeliness,' Journal of Accounting and Economics 39 (1), 83-128.

3. Bartov, E., Givoly, D. and Hayn, C. (2002), 'The rewards to meeting or beating earnings expectations,' Journal of Accounting and Economics 33, 173-204.

4. Beaver, W. H. (1966), 'Financial ratios as predictors of failure,' Journal of Accounting Research 5 (Supplement), 71-111.

5. Beneish, M. D. (2001), 'Earnings management: A perspective,' Managerial Finance 27 (12), 3-17.

6. Beneish, M. D. and Press, E. G. (1993), 'Costs of technical violation of accountingbased debt covenants,' The Accoutning Review 68 (2), 233-257. 
7. Beneish, M. D., Press E., and Vargus, M. (2012), 'Insider Trading and Earnings Management in Distressed Firms,' Contemporary Accounting Research 29, 191-220.

8. Burgstahler, D. and Dichev, I. (1997). 'Earnings Management to Avoid Earnings Decreases and Losses,' Journal of Accounting and Economics 24 (1), 99-126.

9. Capalbo, F. (2003), 'Domestic Practice, Comparative International Analyses and Accounting Discretion - Italian Savings Banks' Pensions Cost Accounting,' Abacus 39 (1), 66-81.

10. Campa, D. and Camacho-Miñano, M. (2014), 'Earnings management among bankrupt non-listed firms: evidence from Spain,' Spanish Journal of Finance and Accounting 43 (1), 3-20.

11. Charitou, A., Lambertides, N., and Trigeorgis, L. (2007a), 'Managerial discretion in distressed firms,' British Accounting Review, $39,323-346$.

12. Charitou, A., Lambertides, N., and Trigeorgis, L. (2007b), 'Earnings behavior of financially distressed firms: The Role of Institutional Ownership,' Abacus 43 (3), 271-296.

13. Charitou, A., Lambertides N. and Trigeorgis, L. (2011), 'Distress Risk, Growth and Earnings Quality,' Abacus, Journal of Accounting, Finance and Business Studies 47 (2), 158181.

14. Charitou, A., Neophytou, E. and Charalambous, C. (2004), 'Predicting corporate failure: empirical evidence for the UK,' European Accounting Review 13 (3), 465-497.

15. DeAngelo, L. E. (1986), 'Accounting numbers as market valuation substitutes: A study of management buyouts of public stockholders,' The Accounting Review 61 (3), 400-420.
16. DeAngelo, L. E. (1988), 'Managerial competition, information costs, and corporate governance: The use of accounting performance measures in proxy contests,' Journal of Accounting and Economics 10 (1), 3-36.

17. DeAngelo, H. and DeAngelo, L. (1990), 'Dividend Policy and Financial Distress: An Empirical Investigation of Troubled NYSE Firms,' The Journal of Finance 45 (5), 14151431.

18. DeAngelo, H., DeAngelo, L., and Skinner, D. J. (1994), 'Accounting choice in troubled companies,' Journal of Accounting and Economics 17 (1/2), 113-143.

19. Dechow, P. M. (1994), 'Accounting earnings and cash flows as measures of firm performance: The role of accounting accruals,' Journal of Accounting and Economics 18 (1), 3-42.

20. Dechow, P. M., Ge, W. and Schrand, C. (2010), 'Understanding earnings quality: A review of the proxies their determinants and their consequences,' Journal of Accounting and Economics 50, 344-401.

21. Dechow, P. M., Hutton, A., Kim J. and Sloan, R. (2012). 'Detecting Earnings Management: A New Approach,' Journal of Accounting Research 50 (2), 275-334.

22. Dechow, P. M., Richardson, S. A. and Tuna, I. A. (2003), 'Why are earnings kinky? An examination of the earnings management explanation,' Review of Accounting Studies 8, 355-384.

23. Dechow, P. M. and Sloan, R. (1991), 'Executive incentives and the horizon problem: An empirical investigation,' Journal of Accounting and Economics 14 (1), 51-89.

24. Dechow, P. M., Sloan, R. G., and Sweeny, A. P. (1995), 'Detecting earnings management,' The Accounting Review 70 (2), 193225 . 
25. DeFond, M.L. and Jiambalvo J. (1994), 'Debt Covenant Violations and Manipulation of Accruals,' Journal of Accounting and Economics 17(1/2), 145-176.

26. Demski, J. S., Patell, J. M. and Wolfson, M. A. (1984), 'Decentralized choice of monitoring systems,' The Accounting Review 59 (1), $16-34$.

27. Dichev, I. and Skinner, D. (2002), 'Large Sample Evidence on the Debt Covenant Hypothesis,' Journal of Accounting Research 40 (4), 1091-1123.

28. Dowdell, T. D. and Press, E. (2004), 'The impact of SEC scrutiny on financial statement reporting of in-process research and development expense,' Journal of Accounting and Public Policy 23, 227-244.

29. D`Souza, J., Jacob, J. and Ramesh, K. (2001), "The use of accounting flexibility to reduce labor renegotiation costs and manage earnings,' Journal of Accounting and Economics 30, 187-208.

30. Dye, R. A. and Verrecchia, R. E. (1995), 'Discretion vs. uniformity: choices among GAAP,' The Accounting Review 70 (3), 389415.

31. Etemadi, H., Dastgir, M., Momeni, M. and Dehkordi, H. F. (2012), 'Discretionary Accruals Behavior of Iranian Distressed Firms,' Middle Eastern Finance and Economics 16, 44-53.

32. Etemadi, H., Dehkordi, H. F. and Amirkhani K. (2013), 'Effect of auditor opinion on discretionary accruals behavior of distressed firms: Empirical evidences from Iran,' African Journal of Business Management 7 (20), 1956$-1965$.

33. Fields, T. D., Lys, T. Z. and Vincent, L. (2001), 'Empirical research on accounting choice,' Journal of Accounting and Economics 31 (1-3), 255-307.
34. Fink, S. (2002), Crisis management: Planning for the inevitable, Lincoln.

35. Franceschetti, B. M. and Koschtial, C. (2013), 'Do bankrupt companies manipulate earnings more than the non-bankrupt ones?,' Journal of Finance and Accountancy 12, 4-24.

36. Fudenberg, D. and Tirole, J. (1995), 'A Theory of Income and Dividend Smoothing Based on Incumbency Rents,' Journal of Political Economy 103 (1), 75-93.

37. Gerakos, J. (2012), 'Discussion of Detecting Earnings Management: A New Approach,' Journal of Accounting Research 50 (2), 335347.

38. Giroux, G. (2006), Earnings Magic and the Unbalance Sheet: The Search for Financial Reality, New York.

39. Godfrey, J., Mather, P. and Ramsay, A. (2003), 'Earnings and Impressions Management in Financial Reports: The Case of CEO Changes,' Abacus 39 (1), 95-123.

40. Gunny, K. (2006), 'What are the Consequences of Real Earnings Management?,' Working Paper, University of Colorado at Boulder.

41. HassabElnaby, H. R., Mosebach, M. and Whisenant, S. (2005), 'The effect of technical default cost on discretionary accounting decisions,' [Online], [Retrieved December 15, 2014],

42. http://papers.ssrn.com/sol3/papers.cfm ?abstract_id $=660802$

43. Haw, O.-H., Qi, D., Wu, D. \& Wu, W. (2005), 'Market Consequences of Earnings Management in response to Security Regulations in China,' Contemporary Accounting Research 22 (1), 95-140.

44. Healy, P. M. (1985), 'The effect of bonus schemes on accounting decisions,' Journal of Accounting and Economics 7 (1-3 April), 85107 
45. Healy, P. M. and Palepu, K. G. (1990), 'Effectiveness of accounting-based dividend covenants,' Journal of Accounting and Economics 12 (1-3), 97-123.

46. Healy, P. M. and Wahlen, J. M. (1999), 'A review of the earnings management literature and its implications for standards setting,' Accounting Horizons 13 (4), 365-383.

47. Holthausen, R. and Leftwich, R. (1983), 'The economic consequences of accounting choice: implications of costly contracting and monitoring,' Journal of Accounting and Economics 5, 77-117.

48. Jones, J. J. (1991), 'Earnings management during import relief investigations,' Journal of Accounting Research 29 (2), 193-228.

49. Jorissen, A. and Otley, D. (2010), 'The management of accounting numbers: case study evidence from the "crash" of an airline,' Accounting and Business Research 1, 3-38.

50. Kalunki, J.-P. and Martikainen, T. (1999), 'Financial failure and managers'accounting responses: Finnish evidence,' Journal of Multinational Financial Management 9, 15-26.

51. Kang, S-H. and Sivaramakrishnan, K. (1995), 'Issues in testing earnings management and an instrumental variable approach,' Journal of Accounting Research 33 (2), 353-367.

52. Kasznik, R. (1999), 'On the association between voluntary disclosure and earnings management,' Journal of Accounting Research 37 (1), 57-81.

53. Kinnunen, J., Kasanen, E. and Niskanen, J. (1995), 'Earnings management and the economy sector hypothesis: Empirical evidence on a converse relationship in the Finnish case,' Journal of Business Finance \& Accounting 22 (4), 497-520.

54. Kothari, S. P., Leone, A. L. and Wasley, C. E. (2005), 'Performance matched discretio- nary accrual measures,' Journal of Accounting and Economics 39 (1), 163-197.

55. Krull, L. K. (2004), 'Permanently Reinvested Foreign Earnings, Taxes and Earnings Management,' The Accounting Review 79 (3), 745-767.

56. Lara, J. M. G., Osma, B. G., and Neophytou, E. (2009), 'Earnings quality in ex-post failed firms,' Accounting and Business Research 39 (2), 119-138.

57. Latridis, G. and Dimitras, A. I. (2013), 'Financial crisis and accounting quality: Evidence from five European countries,' $A d$ vances in Accounting, incorporating Advances in International Accounting 29, 154-160.

58. Leach, R. and Newsom, A. P. (2007), 'Do firms manage their earnings prior to filing for bankruptcy?' Academy of Accounting and Financial Studies Journal 11 (3), 125-137.

59. Leftwich, R. (1980), 'Market failure fallacies and accounting information,' Journal of Accounting and Economics 2, 193-211.

60. Leuz, C., Nanda, D. and Wysocki, P. (2003), 'Earnings management and investor protection: an international comparison,' Journal of Financial Economics 69 (3), 505527.

61. Li, F., Abeysekera, I. and Ma, S. (2011), 'Earnings management and the effect of earnings quality in relation to stress level and bankruptcy level of Chinese listed firms,' Corporate Ownership and Control 9 (1), 366391.

62. Lilien, S., Mellman, M. and Pastena, V. (1998), 'Accounting Changes: successful versus unsuccessful firms,' The Accounting Review 63, (4), 642-656.

63. Louis, H. and Robinson, D. (2005), 'Do managers credibly use accruals to signal private information? Evidence from the pricing of discretionary accruals around stock splits,' 
Journal of Accounting and Economics 39, 361380.

64. Matsunaga, S.R. and Park, C.W. (2001), 'The Effect of Missing a Quarterly Earnings Benchmark on the CEO's Annual Bonus,' The Accounting Review 76, 313-332.

65. McKeown, J., Mutchler, J. and Hopwood, W. (1991), 'Towards an explanation of auditor failure to modify the audit opinion of bankrupt companies,' Auditing: A Journal of Practice and Theory 10 (Supplement), 1-13.

66. McNichols, M. and Wilson, G. P. (1988), 'Evidence of Earnings Management from the Provision for Bad Debts,' Journal of Accounting Research 26, 1-31.

67. Miller, P. B.W. and Bahnson, P. R. (2002), Quality Financial Reporting, New York.

68. Modigliani, F. and Miller, M. (1958), 'The cost of capital, corporation finance and the theory of investment,' American Economic Review 48, 261-297.

69. Mohapatra, S. (2011), 'Earnings Management, Human Rationality, and Relative Deprivation - Some Critical Assessments' [Online], [Retrieved January 5, 2015]

70. http://dspace.unive.it/bitstream/handle /10579/1051/Siddharth2011.pdf?sequence $=1$

71. Monem, R. M. (2003), 'Earnings Management in Response to the Introduction of the Australian Gold Tax,' Contemporary Accounting Research 20 (4), 747-774.

72. Naidu, D. and Patel, A. (2013), 'A Comparison of Qualitative and Quantitative Methods of Detecting Earnings Management: Evidence from two Fijian Private and two Fijian State-owned Entities,' Australasian Accounting Business and Finance Journal 7 (1), 79-98.

73. Peltier-Rivest, D. (1999), 'The determinants of accounting choices in troubled com- panies,' Quarterly Journal of Business and Economics 38 (4), 28-44.

74. Pourciau, S. (1993), 'Earnings Management and Nonroutine Executive Changes,' Journal of Accounting and Economics 16 (1-3), 80-150.

75. Reitenga, A. L. and Tearney, M. G. (2003), 'Mandatory CEO Retirements, Discretionary Accruals and Corporate Governance Mechanisms,' Journal of Accounting, Auditing and Finance 82 (2), 255-280.

76. Ronen, J. and Yaari, V. (2008), Earnings Management. Emerging Insight in Theory, Practice, and Research, New York.

77. Rosner, R. (2003), 'Earnings manipulation in failing firms,' Contemporary Accounting Research 20 (2), 361-408.

78. Roychowdhury, S. (2003), 'Management of earnings through the manipulation of real activities that affect cash flow from operations,' Working Paper, MIT.

79. Roychowdhury, S. (2006), 'Earnings management through real activities manipulation,' Journal of Accounting \& Economics, 42, 335-370.

80. Saleh, N. M. and Ahmed, K. (2005), 'Earnings management of distressed firms during debt renegotiation,' Accounting and Business Research 35 (1), 69-86.

81. Sankar, M. R. and Subramanyam, K. R. (2001), 'Reporting discretion and private information communication through earnings,' Journal of Accounting Research 39 (2), 365-386.

82. Scott, W. R. (2003), Financial Accounting Theory. Second edition. Upper Saddle River, NJ. 
83. Schipper, K. (1989), 'Commentary on earnings management,' Accounting Horizons, 3 (4), 91-102.

84. Shane, P. B. and Stock, T. (2006), 'Security Analyst and Stock market Efficiency in Anticipating Tax-motivated Income Shifting,' The Accounting Review 81 (1), 227-250.

85. Smith, M., Kestel, J. and Robinson, P. (2001), 'Economic recession, corporate distress and income increasing accounting policy choice,' Accounting Forum 25 (4), 335352.

86. Sweeney, A. P. (1994), 'Debt-covenant violations and managers accounting responses,' Journal of Accounting and Economics 17 (3), 281-308.

87. Theo, S. H., Welch, I. and Wong, T. J. (1998), 'Earnings Management and the Un- derperformance of Seasoned Equity Offerings,' Journal of Financial Economics 50, 6399.

88. Tucker, J. W. and Zarowin, P. A. (2006), 'Does Income Smoothing Improve Earnings Informativeness?,' The Accounting Review 81 (1), 251-270.

89. Verbruggen, S., Christaens, J. and Milis, K. (2008), 'Earnings management: a literature review,' Hub Research paper 14, 1-27.

90. Vladu, A. B. (2013), 'Earnings management occurence in times of crisis: insights from the literature,' Annals of the Constantin Barncusi University 5, 115-119.

91. Watts, R. L. and Zimmermann, J. L. (1986), Positive accounting theory. PrenticeHall, Englewood Cliffs, NJ. 